\title{
Elements of 3D Bioprinting in Periodontal Regeneration: Frontiers and Prospects
}

\author{
Ziyi Wang ${ }^{1,2}$ and Xin Huang ${ }^{2,3, *}$ \\ 1 Hospital of Stomatology, Guanghua School of Stomatology, Sun Yat-sen University, \\ Guangzhou 510030, China; wangzy39@mail2.sysu.edu.cn \\ 2 Guangdong Provincial Key Laboratory of Stomatology, Sun Yat-sen University, Guangzhou 510055, China \\ 3 Department of Periodontology, Guanghua School and Hospital of Stomatology, Sun Yat-sen University, \\ Guangzhou 510055, China \\ * Correspondence: huangx275@mail.sysu.edu.cn; Tel.: +86-020-8388-9253
}

check for

updates

Citation: Wang, Z.; Huang, X. Elements of 3D Bioprinting in Periodontal Regeneration: Frontiers and Prospects. Processes 2021, 9, 1724 https://doi.org/10.3390/pr9101724

Academic Editor: Keekyoung Kim

Received: 24 August 2021

Accepted: 22 September 2021

Published: 26 September 2021

Publisher's Note: MDPI stays neutral with regard to jurisdictional claims in published maps and institutional affiliations.

Copyright: (c) 2021 by the authors. Licensee MDPI, Basel, Switzerland. This article is an open access article distributed under the terms and conditions of the Creative Commons Attribution (CC BY) license (https:// creativecommons.org/licenses/by/ $4.0 /)$.

\begin{abstract}
Periodontitis is a chronic infectious disease worldwide, caused by the accumulation of bacterial plaque, which can lead to the destruction of periodontal supporting tissue and eventually tooth loss. The goal of periodontal treatment is to remove pathogenic factors and control the periodontal inflammation. However, the complete regeneration of periodontal supporting tissue is still a major challenge according to current technology. Tissue engineering recovers the injured tissue through seed cells, bio-capable scaffold and bioactive factors. Three-D-bioprinting is an emerging technology in regeneration medicine/tissue engineering, because of its high accuracy and high efficiency, providing a new strategy for periodontal regeneration. This article represents the materials of $3 \mathrm{D}$ bioprinting in periodontal regeneration from three aspects: oral seed cell, bio-scaffold and bio-active factors.
\end{abstract}

Keywords: periodontal regeneration; 3D bioprinting; seed cells; biomaterials

\section{Introduction}

Periodontitis is a common oral infectious disease, the characteristic of which is chronic progressive periodontal tissue destruction [1,2]. Severe alveolar bone resorption caused by periodontitis is one of the leading causes of tooth loss in adults [3]. The aim of periodontitis treatment is not only to control inflammation via mechanical removal of plaque, but also to regenerate the periodontium. The traditional treatment of periodontitis can only achieve long junctional epithelium attachment, which cannot acquire a total periodontal regeneration [4].

Tissue engineering stands out as a top research interest area in medical fields. It combines biological theory and the principles of engineering, helping the injury tissue or organ to recover and restore their function through three elements: seed cells, biocompatible scaffold and bioactive factors [5]. Periodontal regeneration has been a focus of research in oral tissue engineering for a long time. Guide tissue regeneration (GTR) is a common regeneration surgery in periodontology. The stable periodontal alveolar bone recovery after conducting GTR has been proved by several reviews [6-8]. Stem cells isolated from the oral cavity have also been extensively studied in the field of periodontal tissue regeneration, and their potential in the field of periodontal regeneration has been recognized [6,7,9-11]. The microenvironment of the periodontal defect can greatly affect the success rate of GTR, and biocompatible scaffolds provide a stable healing environment for the periodontal tissue to recover. Therefore, creating suitable scaffolds is vital.

Due to the restricted area of the periodontal defects, the construction of scaffolds fitting to the defects' size is challenging. Due to its high accuracy and high efficiency, 3D bioprinting becomes an emerging strategy. Existing 3D bioprinting methods are mainly 
divided into three types: extrusion, droplet-jet bioprinting and photocuring-based bioprinting $[12,13]$. In terms of 3D bioprinting, bio-inks are inevitable. As the main ingredient of 3D bioprinting, it is a composition of biocompatible materials, bioactive factors and cells, to create the ultimate shape of the intended construct, deciding the properties and the biological features of the 3D bioprinting scaffolds, finally influencing the results of periodontal restoration [14].

Thus, how to improve bio-ink to produce more effective implants is crucial. Studies on modifying periodontal scaffolds are carried out on three aspects: (1) find the proper seed cells, with regard to ethical and bio-safety concerns; (2) fabricate better scaffolds, with the innovation of new biocompatible materials and their future clinical application; (3) identify more effective bioactive factors to achieve the whole regeneration of periodontium. In this review, we will summarize the materials of 3D bioprinting technology in the field of periodontal regeneration from three aspects: oral seed cells, biocompatible scaffolds and bioactive factors.

\section{Oral Stem Cell}

Stem cells are a type of cell with multi-differentiation and self-renewal ability, which can be used as seed cells in tissue engineering. Stem cells can produce new stem cells and differentiate into "specific functional cells", such as hemocytes, skin cells, osteocytes, etc. [9].

Due to their multidirectional differentiation and self-renewal ability, stem cells are believed to have a strong potential in regenerating injury tissues and recovering the original functions. This procedure requires bioactive factors or biocompatible scaffolds to promote stem cell proliferation and differentiation [6,9].

In the human body, stem cells are divided into embryonic stem cells and adult stem cells. Embryonic stem cells come from embryos and can differentiate into any cell. Adult stem cells usually exist in related tissues and are an important source of tissue self-renewal and repair. Recent studies have shown that adult stem cells are widely used in oral tissue engineering due to the rich sources of stem cells in the oral cavity [15]. Mesenchymal stem cells are a type of stem cells with great applicational potential. The main source is bone marrow and adipose tissue, but it can also be derived from other tissues, such as placenta, liver, skin, muscle and oral cavity. Stem cells obtained from oral and facial tissues have similar properties to mesenchymal stem cells in vitro, so they are called pluripotent stromal stem cells. They can differentiate into chondrocytes, osteoblasts, muscle cells and adipocytes. Adult stem cells acquired from oral tissue, related to periodontal regeneration, can be divided into dental group and non-dental groups [9,15-19]. (Figure 1), (Table 1).



Figure 1. Stems cell sources in oral cavity. 
Table 1. Characteristics of different types of oral seed cells.

\begin{tabular}{|c|c|c|c|c|}
\hline Types & & Sources & Differentiation and Functions & References \\
\hline \multirow{6}{*}{ Dental } & $\begin{array}{l}\text { Periodontal Ligament } \\
\text { Stem Cells }\end{array}$ & Periodontal ligament & $\begin{array}{c}\text { Osteoblasts } \\
\text { Adipocytes } \\
\text { Chondrocytes } \\
\text { Immunomodulation } \\
\text { Periodontal regeneration }\end{array}$ & [20-24] \\
\hline & $\begin{array}{c}\text { Stem Cells from Human } \\
\text { Exfoliated Deciduous } \\
\text { Teeth }\end{array}$ & $\begin{array}{l}\text { Pulp of the human } \\
\text { exfoliated deciduous } \\
\text { teeth }\end{array}$ & $\begin{array}{c}\text { Adipocytes } \\
\text { Osteoblasts } \\
\text { Odontoblasts } \\
\text { Nerve cells } \\
\text { Hepatocytes } \\
\text { Endothelial cells }\end{array}$ & [20-28] \\
\hline & $\begin{array}{l}\text { Stem Cells from Apical } \\
\text { Papilla }\end{array}$ & Apical papilla & $\begin{array}{c}\text { Odontoblasts } \\
\text { Nerve cells } \\
\text { Hepatocyte-like cells } \\
\text { Periodontal tissue }\end{array}$ & [25-30] \\
\hline & Dental Follicle Stem Cells & Dental follicle & $\begin{array}{c}\text { Osteoblasts } \\
\text { Odontoblasts } \\
\text { Periodontal ligament tissue } \\
\text { Adipocytes } \\
\text { Chondrocytes }\end{array}$ & [29-31] \\
\hline & $\begin{array}{c}\text { Tooth Germ Progenitor } \\
\text { Cells }\end{array}$ & Tooth germ & $\begin{array}{c}\text { Adipocytes } \\
\text { Hepatocytes } \\
\text { Osteoblasts } \\
\text { Neurogenic tissues }\end{array}$ & {$[18,31-33]$} \\
\hline & $\begin{array}{c}\text { Mesenchymal Stem Cells } \\
\text { Derived from Alveolar } \\
\text { Bone }\end{array}$ & Alveolar bone & $\begin{array}{c}\text { Osteoblasts } \\
\text { Adipocytes } \\
\text { Chondrocytes } \\
\text { Immunomodulation }\end{array}$ & {$[18,32-35]$} \\
\hline \multirow{2}{*}{ Non-dental } & $\begin{array}{l}\text { Gingival Mesenchymal } \\
\text { Stem Cells }\end{array}$ & Gingiva & $\begin{array}{l}\text { Adipocytes } \\
\text { Osteoblasts } \\
\text { Chondrocytes }\end{array}$ & {$[18,34-38]$} \\
\hline & $\begin{array}{c}\text { Adipose Derived Stem } \\
\text { Cells }\end{array}$ & Adipose tissue & $\begin{array}{c}\text { Osteoblasts } \\
\text { Periodontal ligament-like tissue } \\
\text { Immunomodulation }\end{array}$ & [36-42] \\
\hline
\end{tabular}

\subsection{Dental Stem Cells}

\subsubsection{Periodontal Ligament Stem Cells}

Periodontal ligament is a vital structure connecting teeth and alveolar bone, and periodontal ligament stem cells (PDLSCs) are pluripotent stem cells extracted from periodontal ligament. PDLSCs are considered to be important stem cells for periodontal regeneration and mandibular defects repair [21]. They can differentiate into alveolar bone and periodontal ligament under the interaction with extracellular membranes, and play an important role in regeneration of oral hard tissue. Existing studies have shown that bone morphogenic proteins (BMPs) can induce the osteogenic effect of PDLSCs [24,43]. Sung-Ho Ha et al. found that Methylsulfonylmethane (MSM) could induce the proliferation and differentiation of PDLSCs into alveolar bone through Smad2/3/Runx2/OSX/OPN axis [20]. Panduwawala CP et al. co-cultured PDLSCs with human umbilical vein endothelial cells in immunodeficiency mice and found new periodontal ligament regenerated at weeks 4 and 8 [44]. Xuan et al. co-cultured M2 macrophages and PDLSCs, which can promote the matrix differentiation of PDLSCs [22]. In vivo, PDLSCs can both differentiate into bonelike mineral tissue and ligament-like fibric tissue with a certain arrangement depending on different growth factors. A single-center clinical trial used PDLSCs and GTR to treat periodontal intrabony defects, finding that alveolar bone height increased significantly 
with 12-month follow-up [45]. Thus, PDLSCs is considered as an important cell source of periodontal regeneration.

\subsubsection{Stem Cells from Human Exfoliated Deciduous Teeth (SHEDs)}

Stem cells from human exfoliated deciduous teeth (SHEDs) have stronger potential to differentiate into other cells in vivo than other stem cells [26]. SHEDs can differentiate into adipocytes, osteoblasts, odontoblasts, nerve cells, hepatocytes and endothelial cells. In the study by Thanaphum Osathanon et al., basic fibroblast growth factor (bFGF) and Jagged1 were found to induce osteogenic differentiation of SHEDs in rats by regulating the expression of alkaline phosphatase [28]. Some studies found cell sheets of SHEDs together with treated dentin matrix can achieve the regeneration of periodontal tissue consisting of periodontal ligament fibers, blood vessels and new alveolar bone [46]. The exfoliated human deciduous teeth stem cells have been used to regenerate periodontal tissue and repair alveolar bone defect because of its high proliferative ability, strong immunosuppressive ability of multiple differentiation, and low carcinogenic risk [27].

\subsubsection{Stem Cells from Apical Papilla}

Stem cells from apical papilla (SCAPs) are mesenchymal stem cells. It was found and extracted from immature root papilla. Proliferation and differentiation ability of dental papilla stem cells are stronger, which are considered to be important cells in oral regenerative medicine. Researches have shown SCAPs have strong potential in dentin regeneration, neurogenic regeneration and hepatocyte-like regeneration [29]. Shu Diao et al. found that activation of the WDR63 signaling pathway can promote osteogenic differentiation of dental papilla stem cells [30]. The study cultured SCAPs cell sheets and transplanted them into nude mice model, finding that SCAPs showed a strong mineral tissue regeneration potential, indicating SCAPs may be used in periodontal hard tissue repair such as alveolar bone defect.

\subsubsection{Dental Follicle Stem Cells}

Dental follicle is loose connective tissue around tooth germ. Dental follicle stem cells (DFCs) are pluripotent stem cells extracted from dental follicle. It can differentiate into osteoblasts, alveolar bone, dentin-like tissue, periodontal ligament tissue, adipocytes, chondrocytes, etc. [31]. Ling-Ling et al. found that DFCs could differentiate into alveolar bone-like morphology under the effect of recombinant human BMP-2n [47]. DFCs have broad application prospects in periodontal regeneration, bio-root regeneration, bone regeneration.

\subsubsection{Tooth Germ Progenitor Cells}

Tooth germ progenitor cells (TGPCs) are the mesenchymal stems obtained from the third molar during the late bell stage of tooth development [33]. Studies have found that TGPCs have strong proliferation and differentiation potential and can differentiate into osteoblasts, hepatocytes and neurogenic tissues [19,32,33]. BMPs, including BMP-2 and BMP-7, can induce the osteogenesis of TGPCs, indicating the TGPCs can be implemented in periodontal regeneration [48].

\subsection{Non-Dental Stem Cells}

\subsubsection{Mesenchymal Stem Cells Derived from Alveolar Bone}

Mesenchymal stem cells derived from alveolar bone (AB-MSCs) are found and extracted from alveolar bone, which is a convenient source of mesenchymal stem cells. AB-MSCs have multi-directional differentiation potential, which can differentiate into osteoblasts, adipocytes and chondrocytes [16,34]. Researchers have used stem cells derived from alveolar bone to repair maxillary cystic bone defects and received an obvious bone regeneration, which indicated AB-MSCs may act as a potential cell source for repairing alveolar bone defect caused by periodontitis [35]. 


\subsubsection{Gingival Mesenchymal Stem Cells}

Gingival mesenchymal stem cells (GMSCs) derive from gingiva, and have shown their potential in periodontitis treatments [37]. Studies showed the proliferation and osteogenic ability of the cells were promoted when cultured with the proper scaffold [38]. A systemic review showed that, compared with other stem cells, GMSCs are easy to obtain, high in proliferation rates and colony-forming efficiency, and can induce a stable periodontal tissue regeneration [36]. Therefore, GMSCs can be a substitute for PDLSCs in periodontal recovery.

\subsubsection{Adipose Derived Stem Cells}

Due to the easy accessibility of adipose tissue and the minimum injury caused by extracting them, adipose-derived stem cells are considered as promising seed cells for tissue engineering. In the study of Morikuni Tobita et.al., they found that adipose-derived stem cells could promote periodontal tissue regeneration with a small amount of newly-formed alveolar bone and periodontal ligament-like tissue observed after 8-week implantation [41]. Studies have reported that adipose-derived stem cells released a series of growth factors related to vascular formation and migration as well as immune-modulation capability and could contribute to the osteogenic differentiation of the periodontal ligament cell $[39,40,42]$.

\section{Biocompatible Materials and Scaffolds}

In oral regenerative medicine, scaffolds and biomaterials are indispensable components. Biomaterial is a kind of material that can interact with both host and implant biological systems. It is often used in the medical field to replace the original structure or tissue. They can be used as attachment sites of cells from surrounding tissues, an important template for tissue regeneration, and a necessary cell source for tissue regeneration $[49,50]$. Therefore, biomaterials should process the features of bioactivity, biocompatibility, biodegradability and bio-inertia [51].

A variety of biological materials, such as natural organic, synthetic organic or inorganic materials, for oral and maxillofacial regeneration, have advantages and disadvantages. Natural organic substances include peptides (collagen or gelatin) and polysaccharides (alginate, chitosan, and agarose). Synthetic organic materials include polylactic acid (PLA), polycaprolactone (PCL), poly (lactic-co-glycolic acid) (PLGA) and polyglycolic acid (PGA) [49-54]. The most commonly used inorganic materials are bioactive ceramics, including glass ceramics or calcium phosphate materials, which have been widely studied as bone defect regeneration materials [12,55]. (Table 2).

Table 2. The advantages and disadvantages of bio-materials.

\begin{tabular}{|c|c|c|c|c|c|}
\hline Types & & & Advantages & Disadvantages & Ref. \\
\hline \multirow{2}{*}{ Organic polymers } & Natural materials & $\begin{array}{l}\text { chitosan, alginate, } \\
\text { polypeptide and } \\
\text { collagen }\end{array}$ & $\begin{array}{l}\text { Excellent hydrophilicity } \\
\text { Preferable biocompatibility } \\
\text { Weak cytotoxicity }\end{array}$ & $\begin{array}{c}\text { Poor mechanical } \\
\text { property } \\
\text { High degrading rate }\end{array}$ & {$[52,56,57]$} \\
\hline & Synthetic materials & $\begin{array}{c}\text { PLA, PCL, PLGA and } \\
\text { PGA }\end{array}$ & $\begin{array}{l}\text { Proper degrading rate } \\
\text { Good physicochemical and } \\
\text { mechanical property }\end{array}$ & $\begin{array}{l}\text { Lack of } \\
\text { bio-conductivity }\end{array}$ & {$[52,58,59]$} \\
\hline Inorganic polymers & Bio-ceramics & $\begin{array}{l}\text { HA } \\
\text { TCP }\end{array}$ & $\begin{array}{c}\text { Comparable structure with } \\
\text { bone } \\
\text { Good osteoinductivity }\end{array}$ & $\begin{array}{l}\text { Hard to degrade } \\
\text { Brittle }\end{array}$ & {$[49,54]$} \\
\hline
\end{tabular}

\subsection{Organic Polymers}

Organic polymers have been widely studied in regeneration medicine, especially in the field of bone regeneration. The organic polymers used in regenerative medicine are mainly biodegradable polymers and have suitable biocompatibility.

Biodegradable polymers, whether natural or synthetic, are good materials for tissue engineering scaffolds. Its degradation mode is very important for its application. 
Biodegradable polymers are mainly divided into enzymatic degradation polymers and hydrolysis polymers [49].

Natural organic polymers, including chitosan, alginate, polypeptide or collagen, and hydrogels, are mainly degraded by enzymes due to their microenvironment. Due to its high plasticity, hydrogel is a good carrier of bioactive molecules and has good biocompatibility and cellular affinity. It becomes an important scaffold material in 3D bioprinting and has an important application in periodontal regeneration [52,56,57]. In the study by Premjit Arpornmaeklong et al., it was found that specific chitosan/collagen ratio in 3D bioprinting thermosensitive $\beta$-glycerophosphate (BGP) chitosan/collagen hydrogel could promote the release of natural flavonoids, thereby affecting the growth and bioactivity of human PDLSCs [56].

Synthetic organic materials such as PLA, PCL, PLGA and PGA are hydrolytic organic polymers. These materials have good physicochemical and mechanical properties, together with various degrading rates in different types. The degradation mechanism of hydrolytic materials involves the degradation of specific chemical bonds and subsequent small molecule diffusion and polymer surface erosion. Surface erosion of polymers forms micromechanical retention with surrounding tissues and enhances the mechanical properties of polymers. However, this kind of material has poor bio-conductivity [50-53]. Therefore, synthetic organic materials are used along with other materials to both enhance the strength of products and acquire certain bioactivity [58]. In the dog periodontal defect model, researchers placed PLGA and PLGA/FGF-2 scaffolds made by electrospinning and the formation of organized periodontal ligament-like tissue was observed. Meanwhile, in vitro, the PLGA/FGF-2 scaffolds can promote the proliferation of PDLSCs [60].

\subsection{Inorganics Materials}

Inorganics materials in regenerative medicine are usually bioactive ceramics, including bio-glass and calcium phosphate, including hydroxyapatite (HA) and $\beta$-tricalcium phosphate (TCP). These two materials have been studied in the field of hard tissue regeneration for a long time. Bioactive ceramic is a solid chemical combination with the surrounding bone tissue, and induces the regeneration of surrounding bone tissue. Hydroxyapatite is chemically and structurally similar to the main components of bone tissue, and has a certain bone induction effect, but it has a poor degrading rate in vivo and in vitro. The structure of $\beta$-tricalcium phosphate is similar to bone tissue, but its degradation rate is faster than hydroxyapatite in vivo. However, using pure TCP to fabricate the scaffold is too brittle to deal with. The strength can be increased by adding synthetic organic materials. Research has found that the printed hybrid TCP/PLA scaffolds showed improved stability and also activated osteoblasts migration $[49,54]$.

\subsection{Biocompatible Scaffolds}

The periodontal ligament is a fibrous connective tissue structure that firmly binds the tooth roots to its surrounding alveolar bone, preventing tooth and alveolar bone from injury during chewing. The highly organized collagen fibers of periodontal ligament oriented perpendicularly to the cementum and the alveolar bone, which plays an important role in the health of periodontium. The existence of cementum and alveolar bone is vital for the function and total restoration of periodontal tissue [61].

In order to regenerate the alveolar bone and tooth cementum, scaffolds with living cells and/or bioactive molecules are needed to form a stable microenvironment. Stem cells such as PDLSCs and other mesenchymal stem cells have achieved a promising result [10,45]. Scaffolds mimics the structure of periodontal tissue for stem cells to conduct their function. They have the ability to guide and promote the recovery process. These scaffolds can consist of one or several components and can be implanted together with stem cells and biologically active factors $[6,12,49,62]$. 


\subsubsection{Monophasic Scaffolds}

The monophasic scaffolds have only one compartment, which meets the requirements of periodontal regeneration: bone-defect stabilization, selective cell proliferation as well as spatial-temporal control of the periodontal healing. Single monophasic scaffolds can directly induce the healing process of periodontal tissue. Carrel, J.P. et al. placed OsteoFlux ${ }^{\circledR}$ (OF), a 3D printed porous scaffold of layered strands of tricalcium phosphate (TCP) and hydroxyapatite (HA), onto the calvaria of 12 adult sheep [63]. They assessed the vertical bone growth led by $\mathrm{OF}$ and compared $\mathrm{OF}$ with particulate bovine bone and particulate TCP. Large volume reconstructions was prevented by the particles. While compared to the controllable linear pores, the arrangement of pores and inter-particle channels of particles cannot be controlled by practationers, accounting for limitation in osteoconduction of particle materials. Therefore, the authors observed a signficant increase in bone growth in the first eight weeks, but no difference in the total four months. Besides, the monophasic scaffolds can also serve as cell delivery and bioactive cues release vectors $[12,64,65]$. With macro- and micro-structure grooved on 3D printed PCL scaffold, Pilipchuk seeded human ligament cells, fibroblasts onto the micropattern and found that the macroscale and microscale features could promote soft mineralized and cementum-like tissue formation [64]. Though cell-based periodontal therapies could promote the periodontal repair, there are considerable limitations, including cell sources collection and culture. Scaffolds loaded with nanoparticles and growth factors can be clinical alternatives and could reach a latent positive outcome [66].

\subsubsection{Multiphasic Scaffolds}

In periodontium, the regeneration of the cementum and the periodontal ligament is equally important with the regeneration of the alveolar bone. Thus, for multi-tissue regeneration, monophasic scaffolds evolve into multiphasic scaffolds, which allow compartmentalized tissue healing that is eventually integrated into a cohesive system [67]. The spatial structure differs in that the multiphasic scaffolds have the closest architecture to the compartmentalized tissue. In other words, multiphasic scaffolds take the key points into consideration: (1) promote the formation of cementum and alveolar bone simultaneously, (2) the appropriate formation of the oriented periodontal ligament fibers that attach to the newly formed alveolar bone and cementum, showing the optimized spatiotemporally control over the periodontal restoration process $[12,68]$.

Multiphasic scaffolds can be categorized into biphasic and triphasic scaffolds [62]. Wang, C.Y. manufactured gingival fibroblast cell-laden biphasic scaffolds by extrusion consist of collagen and strontium-doped calcium silicate. Authors placed the scaffolds onto rabbits cranial and found the bi-layer scaffold enhanced osteogenesis [69]. Costa et al. divided the scaffolds into bone and ligament parts. The bone compartment was made of $\beta-\mathrm{TCP} / \mathrm{PCL}$ and seeded with osteoblasts. The ligament compartment consisted of cell sheet by electrospinning. Researchers implanted it subcutaneously on a slice of dentin in an athymic mouse. They observed the bone formation and the formation of oriented periodontal fibers with increased vascular formation [70]. Based on multiphasic scaffold concepts, Chen, $X$ et.al. developed a triphasic scaffold that was made up of three different phases for each periodontium, respectively, and seeded with periodontal ligament cells. Researchers made the scaffolds with controlled released cementum protein 1 , poly( $\varepsilon$-caprolactone) (PCL) and type I collagen (COL) by electrospinning. They then planted them in the defect rat model for eight weeks. They found after eight weeks, the cementum-like tissue had formed [71]. The use of triphasic scaffolds for periodontal tissue is relatively recent and needs further exploration because of its difficulty in clinical application. The regeneration of periodontal tissue relies on the coordination in the spatialtemporal scale and the main challenge is the regeneration of cementum. 


\subsection{D Bioprinting Techniques}

Three-D bioprinting comes from 3D printing, also known as additive manufacturing, and is one of the practical and promising methods in tissue engineering. Three-D bioprinting overcomes the limitations of fabricating spatial heterogenetic scaffolds, as it aims to mimic the native structure of targeted tissue and individualize the shape to suit the periodontal defects $[13,72]$. The 3D bioprinting techniques can be categorized into extrusion, droplet-jet bioprinting, photocuring-based bioprinting and cell electrospinning. Extrusion is one of the popular 3D bioprinting techniques for the reason that it can use various biomaterials as well as cell spheroids, which can be printed through nozzles [13,73]. Collagen/strontium-doped calcium silicate bi-phasic scaffolds produced by extrusion with fibroblasts ladened could enhance osteogenesis in animal model [69]. Photocuring-based technique is considered as the trend for its high accuracy, speed and resolution. However, because of the limited light-sensitive materials to be used, it cannot be widely used [74,75]. Cell electrospinning receives much attentions as it can fabricate biomimicry scaffolds [76]. Electrospinning fabricated PLGA scaffolds loaded with FGF-2 could release FGF-2 continuously within 21 days and promote the proliferation of PDLSCs [60]. Based on the different principles of various $3 \mathrm{D}$ bioprinting techniques, strength and limitations are list as follows $[73,77,78]$. (Table 3$)$.

Table 3. Strengths and limitations of different 3D bioprinting techniques.

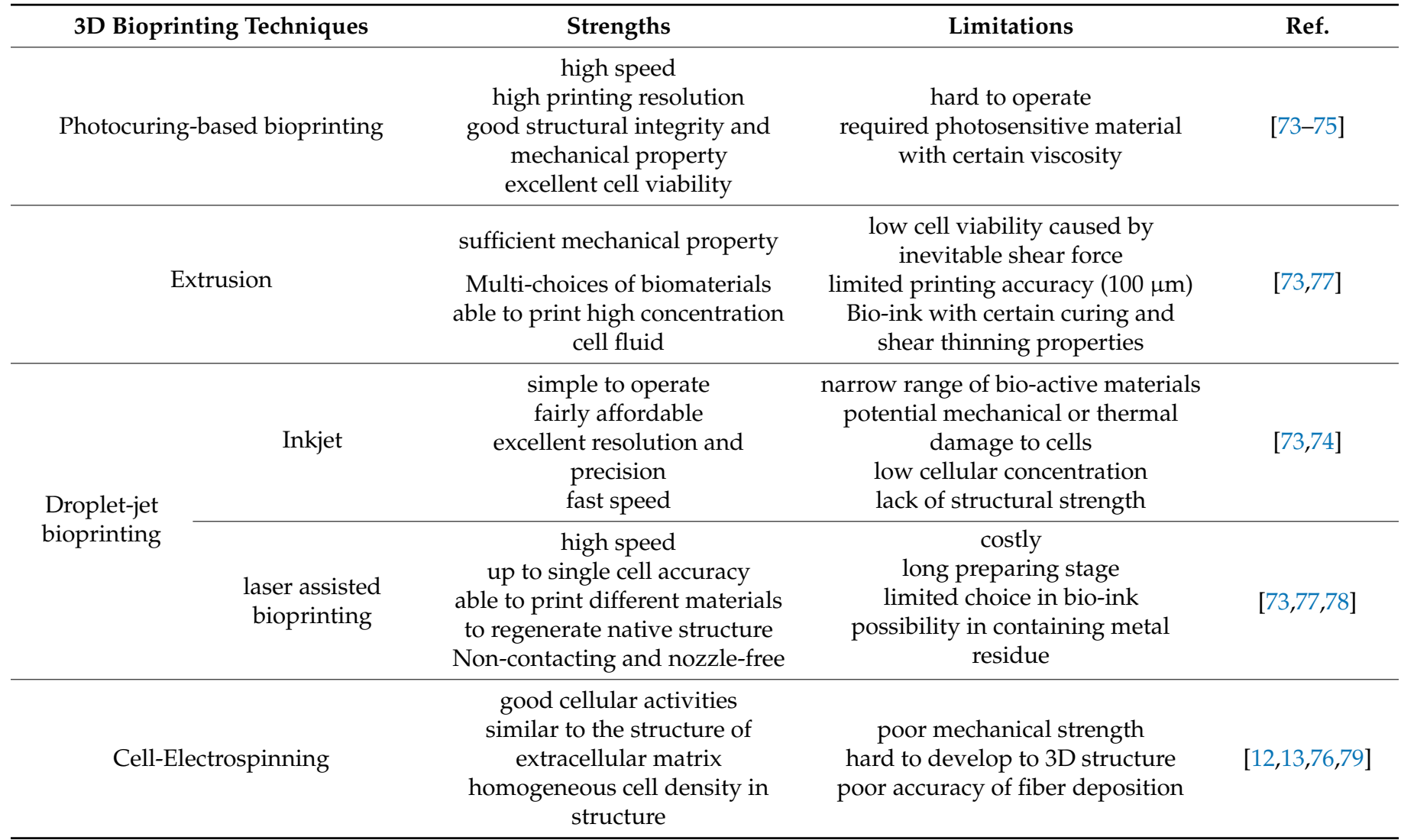

\section{Bioactive Factors}

Bioactive factors act as a key regulating factor in periodontal regeneration. Bioactive molecules can regulate the differentiation of seed cells into periodontal tissues, mobilize the resident stem cells to the defect sites and the recruitment of immune cells to regulate the inflammatory response of damaged sites, thereby promoting periodontal tissue regeneration [6,20,80-82]. Platelet-derived growth factors (PDGFs), bone morphogenetic proteins (BMPs) and enamel matrix derivatives (EMD) are widely used [83]. PDGF is 
derived from autologous platelet concentrates. Researchers found PDGF can promote the proliferation of stem cells and inhibit collagen formation as well as enhancing the bone growth, representing a potential in promoting stem cell based alveolar bone repair $[84,85]$. BMPs are a major influence in osteo-inductivity. BMPs can simulate the function of alkaline phosphatase to simulate bone formation. Besides, BMPs can induce osteoblastic transformation of stem cells [66]. EMD is released during the formation of periodontal tissue. The function of alkaline phosphatase and the cellular viability are promoted when PDLSCs cultured with EMD $[86,87]$. Studies have also shown that drugs can promote the proliferation and differentiation of seed cells. In the study by Liu Qu et al., it was found that $3 \mathrm{D}$ printed hydrogels containing metformin nanocarriers could promote the differentiation of human deciduous tooth stem cells into bone tissue without affecting their cell viability [25]. In addition, the printed-hydrogel together with nanometal particles or other bioactive molecules can also promote the differentiation of different oral stem cells into periodontal tissue and bone tissue $[23,88,89]$.

Meanwhile, bioactive factors play a vital role in endogenous cell homing. Endogenous cell homing is a new concept aiming to solve the problems aroused by vitro stem cell culture, which is to recruit the resident stem cell and direct them to periodontal tissue [6]. Stromal cell-derived factor- $1 \alpha$ (SDF- $1 \alpha)$ is the most common growth factor in recruiting stem cells of patients $[6,90]$. A study found exendin- 4 together with SDF- $1 \alpha$ could promote the cellular viability of PDLSCs [91]. In vivo, hydrogel loaded with SDF-1 $\alpha$ can gather CD90+/CD34stromal cells to achieve in situ periodontal tissue regeneration [57]. Researchers revealed the platelet-rich fibrin and treated dentin matrix could also attract PDLSCs and bone marrow mesenchymal stem cells and accelerate their cell proliferation rate [92]. Although it is still in the laboratory stage, stem-cell homing is a technique with potential, which is more effective, more economical and faster compared with vitro cell culture.

Bioactive molecules are essential to periodontal restoration, since they regulate the signal pathways directing the stem cell biological behaviors, including proliferation, differentiation and endogenous migration. Considering the complicated and interconnected pathways in cells, it is insufficient to figure out the function of a single bioactive factor, which means researches should focus on the function of multi-molecules to move forward in the field of periodontal regeneration.

\section{Challenges and Prospects}

Periodontitis is a chronic inflammation disease caused by bacteria. The loss of tooth sounding tissue caused by periodontitis is unrecoverable. Periodontal surgery is an effective restoration method, including GTR. The oral and maxillofacial region has been considered as a rich source of adult stem cells. Several studies and animal trials have proven that stem cells can perform a promising role in periodontal regeneration $[20,24,35,38,47,60]$. Due to individual heterogeneity, the reaction to implantation and technique sensitivity, the success rate of stem cells is uncertain and the clinical gain of the treatment differs according to different situations. In a randomized controlled trial, 20 patients were enrolled, 10 were treated with TCP, while the cell-treated group received cultured gingival fibroblasts on the TCP scaffold. The cell-treated group was observed to have a significant increase in bone gain after 6 months (average $3.14 \mathrm{~mm}$ ) compared with the controlled (average $1.91 \mathrm{~mm}$ ) [10]. Another randomized controlled trial with 29 patients used micrograft rich in autologous dental pulp stem cells. Clinical and radiographic exams were taken after 6 and 12 months. The bone defect fill is, on average, $3.9 \mathrm{~mm}$ for cell-treated regions versus $1.6 \mathrm{~mm}$ in the control. However, another randomized clinical trial using autologous PDLSCs with 30 patients enrolled and results indicating one-year follow-up showed that the cell-treated group did not appear significantly difference from the non-cell treated group $(2.7 \mathrm{~mm}$ and $2.3 \mathrm{~mm}$ bone gain, respectively) [45]. This may present the problem of the stem cells used in periodontal repair, which is whether patients with periodontal defects can gain more benefits from the application of stem cells. Meanwhile, the ethical and bio-safety concerns cannot be avoided. Besides, both of the trials do not present with a large sample volume 
and are only carried out in a single center. Additionally, the longer-term effect of stem cells still needs to be confirmed via multi-center randomized trials [10,11,45].

The vigorous development of 3D bioprinting technology provides a new solution for periodontal tissue regeneration, scaffolds using biocompatible materials and bioactive particles building a regeneration micro-environment. The current challenge for fabricating the scaffolds is focused on how to regenerate the comparted tissue in the periodontium, respectively. The design of scaffolds, including micropattern and multiphasic structure, etc. provides the possible solutions. Besides, using 3D bioprinting techniques to produce scaffolds is both time-consuming and costly, because of individualized design and the high expense of relative equipment. Bioactive factors play multiple roles in periodontal restoration, including stem cell differentiation, immunomodulation and stem cell homing, etc. Drug delivery systems including nanoparticles and a controlled released system are the main trends of researches in bioactive factors, and the development of a more efficient delivery system is under research [93]. In the meantime, stem-cell homing induced by bioactive agents is a strategy with great implementation possibility, for the reason that stem-cell homing generates individual healing potential and can avoid the ethical concerns relating to the use of stem cells acquired from others. Therefore, future studies on searching for both innovative, effective and affordable scaffolds and bioactive molecules should be developed, which can greatly enhance the periodontal restoration $[2,5,7,9,15-19]$.

Author Contributions: Z.W. and X.H. were responsible for the ideation; writing-original draft preparation, Z.W.; writing-review and editing, Z.W. and X.H. All authors have read and agreed to the published version of the manuscript.

Funding: This study was supported by grants from Undergraduate Teaching Quality Engineering Project of Sun Yat-Sen University (No. 87000-31911131), Guangdong Financial Fund for High-Caliber Hospital Construction (No. 174-2018-XMZC-0001-03-0125/C-01).

Data Availability Statement: The study did not report any data.

Acknowledgments: Authors are thankful to Undergraduate Teaching Quality Engineering Project of Sun Yat-Sen University (No. 87000-31911131), Guangdong Financial Fund for High-Caliber Hospital Construction (No. 174-2018-XMZC-0001-03-0125/C-01).

Conflicts of Interest: The authors declare no conflict of interest.

\section{Abbreviations}

\section{Glossary}

Guide Tissue Regeneration

Bone Morphogenic Proteins

Methylsulfonylmethane

Periodontal Ligament Stem Cells

Stem Cells from Human Exfoliated Deciduous Teeth

Basic Fibroblast Growth Factor

Stem Cells from Apical Papilla

Dental Follicle Stem Cells

Tooth Germ Progenitor Cells

Mesenchymal Stem Cells Derived from Alveolar Bone

Gingival Mesenchymal Stem Cells

Bone Morphogenic Protein-2

Bone Morphogenic Protein-7

Polylactic Acid

Polycaprolactone

Poly (Lactic-Co-Glycolic Acid)

Polyglycolic Acid

Fibroblast Growth Factor-2

B-Glycerophosphate

Abbreviations
GTR
BMPs
MSM
PDLSCs
SHEDs
bFGF
SCAPs
DFCs
TGPCs
AB-MSCs
GMSCs
BMP-2
BMP-7
PLA
PCL
PLGA
PGA
FGF-2
BGP




$\begin{array}{ll}\text { Hydroxyapatite } & \text { HA } \\ \text { B-Tricalcium Phosphate } & \text { TCP } \\ \text { Platelet-Derived Growth Factors } & \text { PDGFs } \\ \text { Enamel Matrix Derivatives } & \text { EMDs } \\ \text { Stromal Cell-Derived Factor- } 1 \alpha & \text { SDF- } 1 \alpha\end{array}$

\section{References}

1. Slots, J. Periodontitis: Facts, fallacies and the future. Periodontol. 2000 2017, 75, 7-23. [CrossRef] [PubMed]

2. Kim, W.J.; Soh, Y.; Heo, S.M. Recent Advances of Therapeutic Targets for the Treatment of Periodontal Disease. Biomol. Ther. 2021, 29, 263-267. [CrossRef] [PubMed]

3. Tonetti, M.S.; Greenwell, H.; Kornman, K.S. Staging and grading of periodontitis: Framework and proposal of a new classification and case definition. J. Periodontol. 2018, 89 (Suppl. 1), S159-S172. [CrossRef] [PubMed]

4. Deas, D.E.; Moritz, A.J.; Sagun, R.S., Jr.; Gruwell, S.F.; Powell, C.A. Scaling and root planing vs. conservative surgery in the treatment of chronic periodontitis. Periodontol. 2000 2016, 71, 128-139. [CrossRef] [PubMed]

5. Tatullo, M.; Marrelli, M.; Paduano, F. The regenerative medicine in oral and maxillofacial surgery: The most important innovations in the clinical application of mesenchymal stem cells. Int. J. Med. Sci. 2015, 12, 72-77. [CrossRef] [PubMed]

6. Liu, J.; Ruan, J.; Weir, M.D.; Ren, K.; Schneider, A.; Wang, P.; Oates, T.W.; Chang, X.; Xu, H.H.K. Periodontal Bone-LigamentCementum Regeneration via Scaffolds and Stem Cells. Cells 2019, 8, 537. [CrossRef]

7. Nunez, J.; Vignoletti, F.; Caffesse, R.G.; Sanz, M. Cellular therapy in periodontal regeneration. Periodontol. 2000 2019, 79, 107-116. [CrossRef] [PubMed]

8. Needleman, I.; Worthington, H.V.; Giedrys-Leeper, E.; Tucker, R. WITHDRAWN: Guided tissue regeneration for periodontal infra-bony defects. Cochrane Database Syst. Rev. 2019, 5, CD001724. [CrossRef]

9. Han, J.; Menicanin, D.; Gronthos, S.; Bartold, P.M. Stem cells, tissue engineering and periodontal regeneration. Aust. Dent. J. 2014, 59 (Suppl. 1), 117-130. [CrossRef] [PubMed]

10. Abdal-Wahab, M.; Abdel Ghaffar, K.A.; Ezzatt, O.M.; Hassan, A.A.A.; El Ansary, M.M.S.; Gamal, A.Y. Regenerative potential of cultured gingival fibroblasts in treatment of periodontal intrabony defects (randomized clinical and biochemical trial). J. Periodontal. Res. 2020, 55, 441-452. [CrossRef]

11. Gorski, B.; Jalowski, S.; Gorska, R.; Zaremba, M. Treatment of intrabony defects with modified perforated membranes in aggressive periodontitis: A 12-month randomized controlled trial. Clin. Oral. Investig. 2018, 22, 2819-2828. [CrossRef]

12. Raveau, S.; Jordana, F. Tissue Engineering and Three-Dimensional Printing in Periodontal Regeneration: A Literature Review. J. Clin. Med. 2020, 9, 4008. [CrossRef]

13. Hong, N.; Yang, G.H.; Lee, J.; Kim, G. 3D bioprinting and its in vivo applications. J. Biomed. Mater. Res. B Appl. Biomater. 2018, 106, 444-459. [CrossRef] [PubMed]

14. D’Avanzo, N.; Bruno, M.C.; Giudice, A.; Mancuso, A.; Gaetano, F.; Cristiano, M.C.; Paolino, D.; Fresta, M. Influence of Materials Properties on Bio-Physical Features and Effectiveness of 3D-Scaffolds for Periodontal Regeneration. Molecules 2021, $26,1643$. [CrossRef] [PubMed]

15. Zhai, Q.; Dong, Z.; Wang, W.; Li, B.; Jin, Y. Dental stem cell and dental tissue regeneration. Front. Med. 2019, 13, 152-159. [CrossRef]

16. Liu, J.; Yu, F.; Sun, Y.; Jiang, B.; Zhang, W.; Yang, J.; Xu, G.T.; Liang, A.; Liu, S. Concise reviews: Characteristics and potential applications of human dental tissue-derived mesenchymal stem cells. Stem. Cells 2015, 33, 627-638. [CrossRef] [PubMed]

17. Hu, L.; Liu, Y.; Wang, S. Stem cell-based tooth and periodontal regeneration. Oral Dis. 2018, 24, 696-705. [CrossRef] [PubMed]

18. Dave, J.R.; Tomar, G.B. Dental Tissue-Derived Mesenchymal Stem Cells: Applications in Tissue Engineering. Crit. Rev. Biomed. Eng. 2018, 46, 429-468. [CrossRef] [PubMed]

19. Paz, A.G.; Maghaireh, H.; Mangano, F.G. Stem Cells in Dentistry: Types of Intra- and Extraoral Tissue-Derived Stem Cells and Clinical Applications. Stem Cells Int. 2018, 2018, 4313610. [CrossRef] [PubMed]

20. Ha, S.H.; Choung, P.H. MSM promotes human periodontal ligament stem cells differentiation to osteoblast and bone regeneration. Biochem. Biophys. Res. Commun. 2020, 528, 160-167. [CrossRef] [PubMed]

21. Tomokiyo, A.; Wada, N.; Maeda, H. Periodontal Ligament Stem Cells: Regenerative Potency in Periodontium. Stem Cells Dev. 2019, 28, 974-985. [CrossRef]

22. Li, X.; He, X.T.; Kong, D.Q.; Xu, X.Y.; Wu, R.X.; Sun, L.J.; Tian, B.M.; Chen, F.M. M2 Macrophages Enhance the Cementoblastic Differentiation of Periodontal Ligament Stem Cells via the Akt and JNK Pathways. Stem Cells 2019, 37, 1567-1580. [CrossRef]

23. Ma, Y.; Ji, Y.; Zhong, T.; Wan, W.; Yang, Q.; Li, A.; Zhang, X.; Lin, M. Bioprinting-Based PDLSC-ECM Screening for in Vivo Repair of Alveolar Bone Defect Using Cell-Laden, Injectable and Photocrosslinkable Hydrogels. ACS Biomater. Sci. Eng. 2017, 3 , 3534-3545. [CrossRef]

24. Hyun, S.Y.; Lee, J.H.; Kang, K.J.; Jang, Y.J. Effect of FGF-2, TGF-beta-1, and BMPs on Teno/Ligamentogenesis and Osteo/Cementogenesis of Human Periodontal Ligament Stem Cells. Mol. Cells 2017, 40, 550-557. [CrossRef] [PubMed]

25. Qu, L.; Dubey, N.; Ribeiro, J.S.; Bordini, E.A.F.; Ferreira, J.A.; Xu, J.; Castilho, R.M.; Bottino, M.C. Metformin-loaded nanospheresladen photocrosslinkable gelatin hydrogel for bone tissue engineering. J. Mech. Behav. Biomed. Mater. 2021, 116, 104293. [CrossRef] [PubMed] 
26. Taguchi, T.; Yanagi, Y.; Yoshimaru, K.; Zhang, X.Y.; Matsuura, T.; Nakayama, K.; Kobayashi, E.; Yamaza, H.; Nonaka, K.; Ohga, S.; et al. Regenerative medicine using stem cells from human exfoliated deciduous teeth (SHED): A promising new treatment in pediatric surgery. Surg. Today 2019, 49, 316-322. [CrossRef] [PubMed]

27. Gao, X.; Shen, Z.; Guan, M.; Huang, Q.; Chen, L.; Qin, W.; Ge, X.; Chen, H.; Xiao, Y.; Lin, Z. Immunomodulatory Role of Stem Cells from Human Exfoliated Deciduous Teeth on Periodontal Regeneration. Tissue Eng. Part. A 2018, 24, 1341-1353. [CrossRef]

28. Osathanon, T.; Nowwarote, N.; Manokawinchoke, J.; Pavasant, P. bFGF and JAGGED1 regulate alkaline phosphatase expression and mineralization in dental tissue-derived mesenchymal stem cells. J. Cell Biochem. 2013, 114, 2551-2561. [CrossRef] [PubMed]

29. Kang, J.; Fan, W.; Deng, Q.; He, H.; Huang, F. Stem Cells from the Apical Papilla: A Promising Source for Stem Cell-Based Therapy. Biomed. Res. Int. 2019, 2019, 6104738. [CrossRef] [PubMed]

30. Diao, S.; Yang, D.M.; Dong, R.; Wang, L.P.; Wang, J.S.; Du, J.; Wang, S.L.; Fan, Z. Enriched trimethylation of lysine 4 of histone H3 of WDR63 enhanced osteogenic differentiation potentials of stem cells from apical papilla. J. Endod. 2015, 41, 205-211. [CrossRef]

31. Zhou, T.; Pan, J.; Wu, P.; Huang, R.; Du, W.; Zhou, Y.; Wan, M.; Fan, Y.; Xu, X.; Zhou, X.; et al. Dental Follicle Cells: Roles in Development and Beyond. Stem Cells Int. 2019, 2019, 9159605. [CrossRef] [PubMed]

32. Tasli, P.N.; Dogan, A.; Demirci, S.; Sahin, F. Myogenic and neurogenic differentiation of human tooth germ stem cells (hTGSCs) are regulated by pluronic block copolymers. Cytotechnology 2016, 68, 319-329. [CrossRef] [PubMed]

33. Ikeda, E.; Yagi, K.; Kojima, M.; Yagyuu, T.; Ohshima, A.; Sobajima, S.; Tadokoro, M.; Katsube, Y.; Isoda, K.; Kondoh, M.; et al. Multipotent cells from the human third molar: Feasibility of cell-based therapy for liver disease. Differentiation 2008, 76, 495-505. [CrossRef] [PubMed]

34. Cao, C.; Tarle, S.; Kaigler, D. Characterization of the immunomodulatory properties of alveolar bone-derived mesenchymal stem cells. Stem Cell Res. Ther. 2020, 11, 102. [CrossRef]

35. Redondo, L.M.; Garcia, V.; Peral, B.; Verrier, A.; Becerra, J.; Sanchez, A.; Garcia-Sancho, J. Repair of maxillary cystic bone defects with mesenchymal stem cells seeded on a cross-linked serum scaffold. J. Craniomaxillofac. Surg. 2018, 46, 222-229. [CrossRef]

36. Li, Q.; Yang, G.; Li, J.; Ding, M.; Zhou, N.; Dong, H.; Mou, Y. Stem cell therapies for periodontal tissue regeneration: A network meta-analysis of preclinical studies. Stem. Cell Res. Ther. 2020, 11, 427. [CrossRef]

37. Gao, X.; Cao, Z. Gingiva-derived Mesenchymal Stem Cells and Their Potential Applications in Oral and Maxillofacial Diseases. Curr. Stem Cell Res. Ther. 2020, 15, 43-53. [CrossRef]

38. Cristaldi, M.; Mauceri, R.; Campisi, G.; Pizzo, G.; Alessandro, R.; Tomasello, L.; Pitrone, M.; Pizzolanti, G.; Giordano, C. Growth and Osteogenic Differentiation of Discarded Gingiva-Derived Mesenchymal Stem Cells on a Commercial Scaffold. Front. Cell Dev. Biol. 2020, 8, 292. [CrossRef]

39. Mohammed, E.; Khalil, E.; Sabry, D. Effect of Adipose-Derived Stem Cells and Their Exo as Adjunctive Therapy to Nonsurgical Periodontal Treatment: A Histologic and Histomorphometric Study in Rats. Biomolecules 2018, 8, 167. [CrossRef]

40. Venkataiah, V.S.; Handa, K.; Njuguna, M.M.; Hasegawa, T.; Maruyama, K.; Nemoto, E.; Yamada, S.; Sugawara, S.; Lu, L.; Takedachi, M.; et al. Periodontal Regeneration by Allogeneic Transplantation of Adipose Tissue Derived Multi-Lineage Progenitor Stem Cells in vivo. Sci. Rep. 2019, 9, 921. [CrossRef]

41. Tobita, M.; Uysal, A.C.; Ogawa, R.; Hyakusoku, H.; Mizuno, H. Periodontal tissue regeneration with adipose-derived stem cells. Tissue Eng. Part A 2008, 14, 945-953. [CrossRef]

42. Kocan, B.; Maziarz, A.; Tabarkiewicz, J.; Ochiya, T.; Banas-Zabczyk, A. Trophic Activity and Phenotype of Adipose Tissue-Derived Mesenchymal Stem Cells as a Background of Their Regenerative Potential. Stem. Cells Int. 2017, 2017, 1653254. [CrossRef]

43. Kang, W.; Liang, Q.; Du, L.; Shang, L.; Wang, T.; Ge, S. Sequential application of bFGF and BMP-2 facilitates osteogenic differentiation of human periodontal ligament stem cells. J. Periodontal. Res. 2019, 54, 424-434. [CrossRef]

44. Panduwawala, C.P.; Zhan, X.; Dissanayaka, W.L.; Samaranayake, L.P.; Jin, L.; Zhang, C. In Vivo periodontal tissue regeneration by periodontal ligament stem cells and endothelial cells in three-dimensional cell sheet constructs. J. Periodontal. Res. 2017, 52, 408-418. [CrossRef]

45. Chen, F.M.; Gao, L.N.; Tian, B.M.; Zhang, X.Y.; Zhang, Y.J.; Dong, G.Y.; Lu, H.; Chu, Q.; Xu, J.; Yu, Y.; et al. Treatment of periodontal intrabony defects using autologous periodontal ligament stem cells: A randomized clinical trial. Stem. Cell Res. Ther. 2016, 7, 33. [CrossRef]

46. Yang, X.; Ma, Y.; Guo, W.; Yang, B.; Tian, W. Stem cells from human exfoliated deciduous teeth as an alternative cell source in bio-root regeneration. Theranostics 2019, 9, 2694-2711. [CrossRef] [PubMed]

47. Zhang, R.; Li, C.; Zhang, S.; Ma, X.; Xiao, R.; Liu, H. Effects of rhBMP-2 on Bone Formation Capacity of Rat Dental Stem/Progenitor Cells from Dental Follicle and Alveolar Bone Marrow. Stem. Cells Dev. 2021, 30, 441-457. [CrossRef]

48. Tasli, P.N.; Aydin, S.; Yalvac, M.E.; Sahin, F. Bmp 2 and bmp 7 induce odonto- and osteogenesis of human tooth germ stem cells. Appl. Biochem. Biotechnol. 2014, 172, 3016-3025. [CrossRef] [PubMed]

49. Matichescu, A.; Ardelean, L.C.; Rusu, L.C.; Craciun, D.; Bratu, E.A.; Babucea, M.; Leretter, M. Advanced Biomaterials and Techniques for Oral Tissue Engineering and Regeneration-A Review. Materials 2020, 13, 5303. [CrossRef] [PubMed]

50. Maurus, P.B.; Kaeding, C.C. Bioabsorbable implant material review. Oper. Tech. Sports Med. 2004, 12, 158-160. [CrossRef]

51. Marin, E.; Boschetto, F.; Pezzotti, G. Biomaterials and biocompatibility: An historical overview. J. Biomed. Mater. Res. A 2020, 108, 1617-1633. [CrossRef]

52. Gentile, P.; Chiono, V.; Carmagnola, I.; Hatton, P.V. An overview of poly(lactic-co-glycolic) acid (PLGA)-based biomaterials for bone tissue engineering. Int. J. Mol. Sci. 2014, 15, 3640-3659. [CrossRef] 
53. Elmowafy, E.M.; Tiboni, M.; Soliman, M.E. Biocompatibility, biodegradation and biomedical applications of poly(lactic acid)/poly(lactic-co-glycolic acid) micro and nanoparticles. J. Pharm. Investig. 2019, 49, 347-380. [CrossRef]

54. Ferrage, L.; Bertrand, G.; Lenormand, P.; Grossin, D.; Ben-Nissan, B. A review of the additive manufacturing (3DP) of bioceramics: Alumina, zirconia (PSZ) and hydroxyapatite. J. Aust. Ceram. Soc. 2016, 53, 11-20. [CrossRef]

55. Mansour, A.; Abu Nada, L.; El-Hadad, A.A.; Mezour, M.A.; Ersheidat, A.; Al-Subaie, A.; Moussa, H.; Laurenti, M.; Kaartinen, M.T.; Tamimi, F. Biomimetic trace metals improve bone regenerative properties of calcium phosphate bioceramics. J. Biomed. Mater. Res. A 2021, 109, 666-681. [CrossRef]

56. Arpornmaeklong, P.; Sareethammanuwat, M.; Apinyauppatham, K.; Boonyuen, S. Characteristics and biologic effects of thermosensitive quercetin-chitosan/collagen hydrogel on human periodontal ligament stem cells. J. Biomed. Mater. Res. B Appl. Biomater. 2021, 109, 1656-1670. [CrossRef] [PubMed]

57. Liu, S.; Wang, Y.N.; Ma, B.; Shao, J.; Liu, H.; Ge, S. Gingipain-Responsive Thermosensitive Hydrogel Loaded with SDF-1 Facilitates In Situ Periodontal Tissue Regeneration. ACS Appl. Mater. Interfaces 2021, 13, 36880-36893. [CrossRef] [PubMed]

58. Park, J.; Lee, S.J.; Jung, T.G.; Lee, J.H.; Kim, W.D.; Lee, J.Y.; Park, S.A. Surface modification of a three-dimensional polycaprolactone scaffold by polydopamine, biomineralization, and BMP-2 immobilization for potential bone tissue applications. Colloids Surf. B Biointerfaces 2021, 199, 111528. [CrossRef] [PubMed]

59. Verardi, S.; Lombardi, T.; Stacchi, C. Clinical and Radiographic Evaluation of Nanohydroxyapatite Powder in Combination with Polylactic Acid/Polyglycolic Acid Copolymer as Bone Replacement Graft in the Surgical Treatment of Intrabony Periodontal Defects: A Retrospective Case Series Study. Materials 2020, 13, 269. [CrossRef]

60. Jiang, L.; Ding, Z.; Xia, S.; Liu, Y.; Lei, S.; Zhong, M.; Chen, X. Poly lactic-co-glycolic acid scaffold loaded with plasmid DNA encoding fibroblast growth factor-2 promotes periodontal ligament regeneration of replanted teeth. J. Periodontal. Res. 2020, 55, 488-495. [CrossRef] [PubMed]

61. Sculean, A.; Chapple, I.L.C.; Giannobile, W.V. Wound models for periodontal and bone regeneration: The role of biologic research Periodontol. 2000 2015, 68, 7-20. [CrossRef] [PubMed]

62. Woo, H.N.; Cho, Y.J.; Tarafder, S.; Lee, C.H. The recent advances in scaffolds for integrated periodontal regeneration. Bioact Mater. 2021, 6, 3328-3342. [CrossRef] [PubMed]

63. Carrel, J.P.; Wiskott, A.; Moussa, M.; Rieder, P.; Scherrer, S.; Durual, S. A 3D printed TCP/HA structure as a new osteoconductive scaffold for vertical bone augmentation. Clin. Oral Implant. Res. 2016, 27, 55-62. [CrossRef] [PubMed]

64. Pilipchuk, S.P.; Monje, A.; Jiao, Y.; Hao, J.; Kruger, L.; Flanagan, C.L.; Hollister, S.J.; Giannobile, W.V. Integration of 3D Printed and Micropatterned Polycaprolactone Scaffolds for Guidance of Oriented Collagenous Tissue Formation In Vivo. Adv. Healthc. Mater. 2016, 5, 676-687. [CrossRef]

65. Cho, H.; Tarafder, S.; Fogge, M.; Kao, K.; Lee, C.H. Periodontal ligament stem/progenitor cells with protein-releasing scaffolds for cementum formation and integration on dentin surface. Connect. Tissue Res. 2016, 57, 488-495. [CrossRef]

66. Sheikh, Z.; Javaid, M.A.; Hamdan, N.; Hashmi, R. Bone Regeneration Using Bone Morphogenetic Proteins and Various Biomaterial Carriers. Materials 2015, 8, 1778-1816. [CrossRef]

67. Ivanovski, S.; Vaquette, C.; Gronthos, S.; Hutmacher, D.W.; Bartold, P.M. Multiphasic scaffolds for periodontal tissue engineering. J. Dent. Res. 2014, 93, 1212-1221. [CrossRef]

68. Zeng, W.Y.; Ning, Y.; Huang, X. Advanced technologies in periodontal tissue regeneration based on stem cells: Current status and future perspectives. J. Dent. Sci. 2021, 16, 501-507. [CrossRef]

69. Wang, C.Y.; Chiu, Y.C.; Lee, A.K.; Lin, Y.A.; Lin, P.Y.; Shie, M.Y. Biofabrication of Gingival Fibroblast Cell-Laden Collagen/Strontium-Doped Calcium Silicate 3D-Printed Bi-Layered Scaffold for Osteoporotic Periodontal Regeneration. Biomedicines 2021, 9, 431. [CrossRef]

70. Costa, P.F.; Vaquette, C.; Zhang, Q.; Reis, R.L.; Ivanovski, S.; Hutmacher, D.W. Advanced tissue engineering scaffold design for regeneration of the complex hierarchical periodontal structure. J. Clin. Periodontol. 2014, 41, 283-294. [CrossRef]

71. Chen, X.; Liu, Y.; Miao, L.; Wang, Y.; Ren, S.; Yang, X.; Hu, Y.; Sun, W. Controlled release of recombinant human cementum protein 1 from electrospun multiphasic scaffold for cementum regeneration. Int. J. Nanomedicine. 2016, 11, 3145-3158. [CrossRef]

72. Yu, N.; Nguyen, T.; Cho, Y.D.; Kavanagh, N.M.; Ghassib, I.; Giannobile, W.V. Personalized scaffolding technologies for alveolar bone regenerative medicine. Orthod. Craniofac. Res. 2019, 22 (Suppl. 1), 69-75. [CrossRef]

73. Gu, Z.; Fu, J.; Lin, H.; He, Y. Development of 3D bioprinting: From printing methods to biomedical applications. Asian J. Pharm. Sci. 2020, 15, 529-557. [CrossRef]

74. Trivedi, P.; Liu, R.; Bi, H.; Xu, C.; Rosenholm, J.M.; Akerfelt, M. 3D Modeling of Epithelial Tumors-The Synergy between Materials Engineering, 3D Bioprinting, High-Content Imaging, and Nanotechnology. Int. J. Mol. Sci. 2021, 22, 6225. [CrossRef]

75. Della Bona, A.; Cantelli, V.; Britto, V.T.; Collares, K.F.; Stansbury, J.W. 3D printing restorative materials using a stereolithographic technique: A systematic review. Dent. Mater. 2021, 37, 336-350. [CrossRef]

76. Hong, J.; Yeo, M.; Yang, G.H.; Kim, G. Cell-Electrospinning and Its Application for Tissue Engineering. Int. J. Mol. Sci. 2019, 20, 6208. [CrossRef]

77. Ma, Y.; Xie, L.; Yang, B.; Tian, W. Three-dimensional printing biotechnology for the regeneration of the tooth and tooth-supporting tissues. Biotechnol. Bioeng. 2019, 116, 452-468. [CrossRef]

78. Qu, M.; Wang, C.; Zhou, X.; Libanori, A.; Jiang, X.; Xu, W.; Zhu, S.; Chen, Q.; Sun, W.; Khademhosseini, A. Multi-Dimensional Printing for Bone Tissue Engineering. Adv. Healthc. Mater. 2021, 10, e2001986. [CrossRef] 
79. Zhuang, Y.; Lin, K.; Yu, H. Advance of Nano-Composite Electrospun Fibers in Periodontal Regeneration. Front. Chem. 2019, 7, 495. [CrossRef]

80. Liu, J.; Chen, B.; Bao, J.; Zhang, Y.; Lei, L.; Yan, F. Macrophage polarization in periodontal ligament stem cells enhanced periodontal regeneration. Stem. Cell Res. Ther. 2019, 10, 320. [CrossRef]

81. Chien, K.H.; Chang, Y.L.; Wang, M.L.; Chuang, J.H.; Yang, Y.C.; Tai, M.C.; Wang, C.Y.; Liu, Y.Y.; Li, H.Y.; Chen, J.T.; et al. Promoting Induced Pluripotent Stem Cell-driven Biomineralization and Periodontal Regeneration in Rats with Maxillary-Molar Defects using Injectable BMP-6 Hydrogel. Sci. Rep. 2018, 8, 114. [CrossRef]

82. Nagai, K.; Ideguchi, H.; Kajikawa, T.; Li, X.; Chavakis, T.; Cheng, J.; Messersmith, P.B.; Heber-Katz, E.; Hajishengallis, G. An injectable hydrogel-formulated inhibitor of prolyl-4-hydroxylase promotes T regulatory cell recruitment and enhances alveolar bone regeneration during resolution of experimental periodontitis. FASEB J. 2020, 34, 13726-13740. [CrossRef]

83. Mancini, L.; Romandini, M.; Fratini, A.; Americo, L.M.; Panda, S.; Marchetti, E. Biomaterials for Periodontal and Peri-Implant Regeneration. Materials 2021, 14, 3319. [CrossRef]

84. Pan, J.; Deng, J.; Luo, Y.; Yu, L.; Zhang, W.; Han, X.; You, Z.; Liu, Y. Thermosensitive Hydrogel Delivery of Human Periodontal Stem Cells Overexpressing Platelet-Derived Growth Factor-BB Enhances Alveolar Bone Defect Repair. Stem. Cells Dev. 2019, 28, 1620-1631. [CrossRef]

85. Mihaylova, Z.; Tsikandelova, R.; Sanimirov, P.; Gateva, N.; Mitev, V.; Ishkitiev, N. Role of PDGF-BB in proliferation, differentiation and maintaining stem cell properties of PDL cells in vitro. Arch. Oral. Biol. 2018, 85, 1-9. [CrossRef]

86. Hisanaga, Y.; Suzuki, E.; Aoki, H.; Sato, M.; Saito, A.; Saito, A.; Azuma, T. Effect of the combined use of enamel matrix derivative and atelocollagen sponge scaffold on osteoblastic differentiation of mouse induced pluripotent stem cells in vitro. J. Periodontal. Res. 2018, 53, 240-249. [CrossRef] [PubMed]

87. Li, G.; Hu, J.; Chen, H.; Chen, L.; Zhang, N.; Zhao, L.; Wen, N.; Yang, Y. Enamel matrix derivative enhances the proliferation and osteogenic differentiation of human periodontal ligament stem cells on the titanium implant surface. Organogenesis 2017, 13, 103-113. [CrossRef] [PubMed]

88. Zhang, Y.; Wang, P.; Wang, Y.; Li, J.; Qiao, D.; Chen, R.; Yang, W.; Yan, F. Gold Nanoparticles Promote the Bone Regeneration of Periodontal Ligament Stem Cell Sheets Through Activation of Autophagy. Int. J. Nanomed. 2021, 16, 61-73. [CrossRef] [PubMed]

89. Ma, Y.; Ji, Y.; Huang, G.; Ling, K.; Zhang, X.; Xu, F. Bioprinting 3D cell-laden hydrogel microarray for screening human periodontal ligament stem cell response to extracellular matrix. Biofabrication 2015, 7, 044105. [CrossRef] [PubMed]

90. Xu, X.Y.; Li, X.; Wang, J.; He, X.T.; Sun, H.H.; Chen, F.M. Concise Review: Periodontal Tissue Regeneration Using Stem Cells: Strategies and Translational Considerations. Stem. Cells Transl. Med. 2019, 8, 392-403. [CrossRef]

91. Liang, Q.; Du, L.; Zhang, R.; Kang, W.; Ge, S. Stromal cell-derived factor-1/Exendin-4 cotherapy facilitates the proliferation, migration and osteogenic differentiation of human periodontal ligament stem cells in vitro and promotes periodontal bone regeneration in vivo. Cell Prolif. 2021, 54, e12997. [CrossRef] [PubMed]

92. Ji, B.; Sheng, L.; Chen, G.; Guo, S.; Xie, L.; Yang, B.; Guo, W.; Tian, W. The combination use of platelet-rich fibrin and treated dentin matrix for tooth root regeneration by cell homing. Tissue Eng. Part A 2015, 21, 26-34. [CrossRef] [PubMed]

93. Funda, G.; Taschieri, S.; Bruno, G.A.; Grecchi, E.; Paolo, S.; Girolamo, D.; Del Fabbro, M. Nanotechnology Scaffolds for Alveolar Bone Regeneration. Materials 2020, 13, 201. [CrossRef] [PubMed] 